\title{
COMPARING OECD EDUCATIONAL MODELS THROUGH THE PRISM OF PISA
}

N.Bulle, Comparative Education, January 2011.

This is the author's version of the work. It is posted here by permission of Taylor \& Francis for personal use, not for redistribution.

The definitive version was published in Comparative Education, January 2011. doi:10.1080/03050068.2011.555117

(http://dx.doi.org/10.1080/03050068.2011.555117) 


\section{COMPARING OECD EDUCATIONAL MODELS THROUGH THE PRISM OF PISA}

The PISA survey influences educational policies through an international competitive process which is not wholly rationally-oriented. Firstly, PISA league tables act normatively upon the definition of formal educational aims while the survey tests cannot evaluate the educational systems' relative strengths with regards to such aims. We argue that they measure a kind of academic potential of the students. Secondly, errors in interpreting national success or failure stem from the causal inferences developed from observing national cases. In order to give such comparisons a stronger basis, we distinguish five main educational models within the OECD countries and compare their PISA 2006 results to their population's socio-economic levels as well as their performance recorded in an academic-program-based survey such as TIMSS. Our conclusions contrast heavily with the usual lessons inferred from PISA, which follow OECD-promoted guidelines, and explain French students' weakening as well as Finnish students' success.

\section{Introduction}

The PISA ${ }^{1}$ survey has gained in importance over the years, to the point that it has changed the philosophy of world educational policies. This is an impressive feat but it has been achieved by perverting the original objectives. The comparison of educational systems through rankings and their interpretation are guiding national school policies in a normative fashion. The survey serves as a political tool in the hands of experts and technocrats who directly influence its design and handling. Countries are invited to measure one against the other and to reform their educational systems in the light of their corresponding results. They have been gradually adopting shared ideas with regard to educational objectives and the solutions to be adopted. They tend to model parts of their school policies over practices developed abroad, without conducting a thorough examination of the context. These policy elements are transferred from one country to another according to a dynamics which is

\footnotetext{
${ }^{1}$ Programme for International Student Assessment.
} 
more akin to an epidemics than mutual learning (Levin, 1998). Thus, there has developed an endogenous process of fabricating an educational orthodoxy which lacks real rationality.

The fabrication of an international educational doxa is broadly based on the following process: The simplicity of the method of ranking the educational systems and the commotion that this honours list causes for the nations which are less well ranked turn mass media into privileged channels for disseminating the survey results. In their turn, these results are able to exert pressure over political decision-makers at a national level. They are invited to take action. The comparisons made maintain an environment of competition made up of leading countries from which one retains only the characteristics which one wants to promote, and of countries which act as a foil. Generalities are deduced from particular cases and the counter-examples which contradict the links established are neglected. It is upon this process that normative criteria regarding school policies are developed. The standardisation of the educational discourse and of the solutions advocated has led countries to gradually adopt a shared understanding of 'best practice' and to implement similar policies, so much so that the latter have acquired a trait of 'inevitability' (Novoa \& Yariv-Mashal, 2003).

Because they find themselves under the patronage of international experts, these trends have tended to discourage the thoughtful, enlightened use of the PISA results. This use is also impeded by the difficulty of such an undertaking. It requires a thorough knowledge of the different educational systems, their history and national context. In order to understand their results, one must distinguish between the impact of general characteristics and that of factors more specific to local situations. We would therefore suggest an exploratory analysis which is not based on the performance of the national educational systems but on that of the broad educational models represented by these systems. Thus, we will be able to bring these models general characteristics into a more direct confrontation. This examination of the PISA results is based first on an analysis of the empirical subject of the survey.

\section{What does PISA measure?}

The PISA survey offers a regular (every three years) method of measuring the competencies of a representative sample of 15 -year-old students in three areas which are in turn promoted by the survey: 
written comprehension, mathematical and scientific knowledge. The choice of the 15-year-old age group is justified by the fact that this age marks, in most $\mathrm{OECD}^{2}$ countries, the end of the compulsory education period. PISA's rather peculiar perspective is not to look at the quality of the students' knowledge from the point of view of the studies they follow but, rather, the idea is to evaluate the ability of the students to autonomously cope with situations of everyday life thanks to their school education. This is what the OECD analysts understand by 'literacy'. The PISA tests are designed to be independent of all specific educational programmes. This choice is not explained only by the difficulty of building a 'meta-programme' within which students' knowledge within each of the educational systems can be compared - a survey such as $\mathrm{TIMSS}^{3}$, conducted by IEA, ${ }^{4}$ into the students' mathematical and science competencies has overcome such difficulties. One explanation for PISA's indifference to educational programmes is that the primary aim of the survey is not to serve the school's objectives, but to encourage a spirit of competition so as to help the development of neoliberal policies favoured by OECD (Uljens, 2007). The fact that such a spirit of competition is developed around skills necessary to cope with daily life situations is nevertheless highly significant. As was the case with the definition of the Intellectual Quotient, these skills are in line with an implicit vision of the well-living lifestyle in our societies (Carson, 2001). However, as with the Binet tests, the question that needs to be answered is whether these skills refer to something other than what the tests are measuring. In other words, are the PISA tests well-adapted to their subject, the ability to play a constructive social and economic role in a modern democratic society, and the societies' ability to cope with present and future challenges?

At the beginning of PISA's conception, a research programme was established, under the auspices of the Federal Suisse Office of Statistics, in order to work out a theoretical and conceptual framework ${ }^{5}$

\footnotetext{
${ }^{2}$ Organisation for Economic Co-operation and Development.

${ }^{3}$ Trends in International Mathematics and Science Study.

${ }^{4}$ International Association for the Evaluation of Educational Achievement.

${ }^{5}$ DeSeCo: Definition and Selection of Competencies: Theoretical and Conceptual Foundations.
} 
capable of serving as basis for defining and measuring the competencies targeted (Salganik, Rychen and Konstant, 1999). The work and ideas of these scientists who came from different backgrounds reached no consensus. The risky and reductive nature of a priori defining the general competencies and qualities expected of a modern citizen became apparent. In the case of each possible candidate, the existence of a key competency requires, by necessity, the cultivation of its opposite; for example, flexibility requires perseverance etc. Sociability itself did not appear as a universal requisite whilst the associability of the artist or the academic has to be 'allowed' as well (Goody, 2001). Another important objection to the project of defining key competencies to be developed is that of the crucial role played by types of knowledge and ability linked to specific formal kinds of learning in order to carry out the most difficult tasks: the more general a competency or strategy is, the less it will contribute to solving difficult problems (Weinert 2001). However, this objection does not invalidate the central objective of this survey, which is that of evaluating the students' ability to put most of their knowledge to good use in non-school-related situations, which can cause more or less serious difficulties. In other words, the tasks' absolute level of difficulty matters less here than the evaluation of the pupils' relative ability to overcome them.

In actual fact, the project of defining a theoretical or methodological corpus which the survey could be based on was abandoned and the decision was taken to test the ideas which lay at the origin of the project in a purely empirical way. The approach defined in terms of 'cross-curricular competencies' was thus developed in a globally inductive way and no other attempt of theoretical comprehension was made to serve as reference when designing the tools for evaluation and interpreting the results.

The central question to be answered is to know what competencies are at stake in 'paper-pencil' contexts, i.e. not in real-life contexts but only in those pertaining to evaluation (Dohn 2007; Sjøberg 2007). We can quite safely contend that the survey evaluates competencies related to solving academic types of problems which, nevertheless, are not predefined by academic knowledge. These tests, therefore, are not able to allow us to judge abilities of coping with real-life situations more correctly than the actual academic competencies themselves do. 
A first consequence can be derived from the tests' inadequacy in relation to their objective. The competencies evaluated are potentially better in schools where the educational programmes are oriented towards problem-solving in daily life whilst this superior performance is no proof of an educational advantage with regard to the PISA objectives themselves (Bodin 2007). The programmes in question are certainly useful in terms of improving PISA scores but their usefulness in terms of preparing students for life remains an open-ended question. Over and above the risk of introducing bias, the separation of tests from academic programmes makes the survey potentially more open to influences outside of school than a survey built on taught knowledge.

If, as we in fact hypothesise here, PISA evaluates competencies for solving problems of an academic type independently of academic knowledge, these competencies maintain a tight relationship with the abilities necessary to succeed in one's studies. We will refer to these abilities as 'academic potential' which covers, at one and the same time, general abilities, a certain common sense and the basic abilities necessary to understand and decode the tests offered (Prais, 2003). We can predict, following this hypothesis, that the results obtained by a student in the different areas covered by the survey will be markedly comparable. And this is exactly what is noticed: the average of the correlations between the individual scores in mathematics, sciences and reading, for the whole of a country, is above 0.8 (Cromley, 2009). Let us note the fact that this cross-academic aspect of the results becomes more prominent with the reading results, which tends to reveal the role played by general verbal competencies in this respect. ${ }^{6}$

The hypothesis of the 'academic potential' also presupposes that the relative successful results of the same students in PISA and in surveys based on academic programmes are strongly linked. This is precisely what was noticed in the case of Germany who, in 2000, enlarged the sample of students who took part in the PISA survey twentyfold and added to the international survey (made up of 31 items) questions which were more directly linked to the school programme ( 86 additional items). The correlation between students' successful results in the two sets of tests was estimated at 0.91 , which is

\footnotetext{
${ }^{6} \mathrm{Cf}$. also Vrignaud (2008) on this subject.
} 
extremely high. It highlights the existence of a strong shared dimension which underlies the success at both types of questions, which are based on daily-life situations in one case and on academic problems on the other (Baumert et al., 2001:157).

In short, the real purpose of the evaluations offered by PISA corresponds, in all likelihood, to a general academic potential of the students which is measured independently of the level effectively reached by them in the academic areas concerned. This hypothesis is supported by the globally crossacademic nature of the abilities measured and their very strong link with the students' results within the framework of the national academic programmes. The aim of these PISA tests is therefore meant to be a lot less original than the political decision-makers assume, thinking that the PISA results measure competencies which are more real, better linked to the future personal, social and economic well-being of individuals than those which are linked to the goals of academic teaching.

Finally, a country's success in the PISA survey depends primarily on the development in the majority of the students of a basic academic potential, in other words, of an intellectual 'survival kit'. The survey's magnifying glass tends to be directed at the weaker students. The school and social systems where academic failure is best contained are therefore those which limit the most the disparity between results on the PISA scale and who are most certain to raise the absolute average of their student body on this same scale. It is therefore from this perspective that one must read PISA so that one can learn any eventual lessons and to avoid drawing from it any unsuitable solutions in order to solve problems which, from the very beginning, PISA does not raise.

\section{Defining OECD $\sqsubset$ ideal-typical $\square$ educational models}

In order to compare the relative PISA results obtained by the main types of educational systems, we can distinguish five generic models based on their present characteristics: Northern, Anglo-Saxon, Latin, Germanic and East-Asian. Such generic models represent ideal-typical categories. In order to characterize them, we shall consider two main institutional dimensions: the dominant educational structures and objectives. Overall, one can distinguish three types of curricular organisation during compulsory education, which can cover more or less diverse and complex national situations: 
undifferentiated, mixed, or differentiated by courses of study. The dominant educational objectives are moreover differentiated either through the fact that they are more centred on academic educational programmes (academic type) or on results expected in terms of students' general competencies (progressive type). This typology is presented in table 1.

Table 1

Typology of generic models of OECD educational systems

\begin{tabular}{llll}
\hline Curricular & Undifferentiated & Mixed & Differentiated \\
organisation & & & \\
\hline Academic trend & Latin & East-Asian & Germanic \\
Progressive trend & Northern & Anglo-Saxon & \\
& & & \\
\hline
\end{tabular}

OECD educational models

\section{OECD educational models ${ }^{7}$}

Latin model: France, Greece, Italy, Spain

Northern model: Denmark, Finland, Iceland, Norway, Sweden

Anglo-Saxon model: Australia, Canada, Ireland, New Zealand, United Kingdom, United States

East-Asian model: Japan, South Korea

Germanic model: Austria, Belgium, Germany, Netherlands, Switzerland

The most easily identifiable trend, from a structural point of view, is marked by the students' early orientation towards differentiated courses of study (traditional or Germanic types). However, this can

\footnotetext{
${ }^{7}$ We have ignored, for the purpose of evaluating these school models, the national examples which represent unique cases if we take into account recent political history, the economic situation or the demotion of a country to a city.
} 
be softened not only by practices which witness the diversification of organisational types within the same country but also, as in the case of the Netherlands, by channels of communication within the educational institutions which allow for a crossover between courses of study. The distinction between 'undifferentiated' and 'mixed' types is more delicate since curricular diversification can take various forms at the level of institutions, through school differences, the constitution of same-level groups inside schools or the relative individualisation of the curriculum (modules or options of further studies). The decentralisation of numerous educational systems accentuates this diversity by making schools more open to local specificity. However, the perspective here is uniquely to contrast the principle of a completely shared core curriculum with that of a core curriculum which is partially shared. We shall deem as 'mixed' those curricula which offer ways of further study whilst taking into account the students' knowledge and aspirations in relation to the cumulative subjects (notably mathematics and native language). The Anglo-Saxon model of organising the curriculum generally fits in with this 'mixed' criterion.

The East-Asian system poses an important ambiguity with regard to the question of the shared core curriculum. The notion of equity, which it represents, nevertheless evokes in equal measure those of competition and selection. We have to ask ourselves if these notions compare the compulsory programme to the post-compulsory programme or if they represent contradictory tendencies. The answer tends to require a third hypothesis and involves two complementary sides of the same reality (Shimizu, 1992).

In Japan, the system of examination for entry into high school (second phase of secondary education, lycée in France) and universities determines a classification of the educational institutions based on their students' entry into the best universities. The hierarchy of the universities determines, in the eyes of the public, the social and economic future of the students which attend them. This system is compared to a tournament where winners gain the right to participate in the next stage. In order to prepare for the entry exams for the second phase of secondary education, students are subjected to significant pressure from primary school. 
In South Korea, the selection for admission into high school, the same as into college or university, has a comparable effect on the pressure which students feel from the beginning of their entry at school and which gradually increases. The hierarchy of colleges and universities will also determine the students' future. Of all the factors which can explain young South Koreans' success at international tests, the importance for these students' future of (mathematics-centred) exams for entry into the best secondary and higher educational institutions is presented as the most important one.

Thus, in Japan and South Korea, the gradual selection of students has an overall profound influence on the whole educational system in these countries. It involves tailored training for students which is adapted to their aspirations and abilities. However, this training is generally not provided within the public establishment but via privately provided additional courses. The latter (juku in Japan, hagwon in South Korea), which have developed alongside the expansion of the secondary and higher educational systems, represent veritable institutions in themselves. In South Korea they are a daily addition to the school curriculum, which is more important than the latter to some parents, who allocate a sometimes important part of their salary to it. It is therefore not a rare occurrence for students to finish their day of studying late at night. ${ }^{8}$ In Japan, special private schools offer courses after school hours as well as at the weekends. These schools provide complementary schooling in continuation to regular education, courses which give support but also train with the direct aim of achieving success at the exams for entry into high school. The students' attendance to these schools increases with age and includes around half of the school population. ${ }^{9}$ One cannot understand the way compulsory school works in the East-Asian systems without taking into account what is at stake with the selection for entry into high school and, related to that, the partial differentiation of curricula across the complementary system of private courses. For these reasons we consider the East-Asian

\footnotetext{
${ }^{8} \mathrm{Cf}$. for example:

http://ciu.northcarolina.edu/content.php/docs/southkorea.pdf;

http://www.nctm.org/resources/content.aspx?id=1592.

${ }^{9}$ This evaluation dates from 1994: http://lcweb2.loc.gov/cgi-bin/query/D?cstdy:1:./temp/ frd_jN4o::
} 
model to be one of the "mixed" systems, in spite of the strong homogeneity of shared standards which students face within the framework of the public programme.

The academic versus progressive opposition of educational objectives characterises two extremes between which there lie specific doses of academic and progressive tendencies pertaining to each educational system. Very generally speaking, the academic trend is interested in the progressive and structured development of the teaching of academic subjects. It places the emphasis on theoretical learning involving conscious psychological processes and hypothetical-deductive abilities. The progressive trend contrasts students' activity - underlying genuine understanding- with direct instruction. Whether it follows contemporary constructivism, socio-constructivism, or competencebased approaches - which may more or less overlap -, it does not consider theoretical teaching and formal exercises to be playing an active role in intellectual development. It places the emphasis on empirical learning involving the more subconscious psychological processes which rely on practice and immersion (similar to learning a mother tongue), interpersonal communication, and inductive skills. The tension which opposes the progressive trend to the academic one brings into confrontation ideas of experience, learning by doing, educational situations, competencies, interactions and crosscurricular problems, and ideas of conveying knowledge, conceptual understanding, mental discipline and academic frameworks and problems (Bulle 2009). These differences are mainly reflected by the aims of educational programmes.

From the academic pole to the progressive one, we run through the range of educational models, from explicit to more informal models of developing knowledge and competencies. Thus, we can take the example of a comparison between the teaching of mathematics in Japan, Germany and United States. ${ }^{10}$ Video cameras placed in classrooms $\left(8^{\text {th }}\right.$ grade $)$ show that the typical goal of the American mathematics teacher is to teach students how to do something whilst in Japan it is to help them understand the mathematical concepts. The American teacher tends to deal with subjects which are

\footnotetext{
${ }^{10} \mathrm{Cf}$. http://www.sedl.org/scimath/compass/v03n03/looking.html. The analysis of the video footage led to the following evaluation : $30 \%$ of a mathematics course in Japan had high-quality content, $23 \%$ in Germany and $0 \%$ in United States. Cf. also Stevenson and Stigler (1992).
} 
more diverse but in a manner which is described as superficial. On the contrary, the Japanese teacher tends to connect the different parts of the course. The German teacher is placed somewhere between these two tendencies. Such comparisons and the antiquity of the progressive model in the AngloSaxon countries have led to a questioning of the educational beliefs which were attached to it in the United States and United Kingdom, which further complicates all categorisation of educational systems. On the contrary, the Latin and German systems, which represent the academic tradition, have, to a greater or lesser extent, taken a progressive turn during the last few decades, just as the Northern countries did before them. The progressive trend dominates current school policies but against a background of practices which are more or less academically oriented.

\section{Results: the PISA success}

Starting from the typology previously outlined, we will first look at the overall results of the idealtypical models identified.

\section{Table 2}

Average results associated with the generic models of the OECD educational systems

\begin{tabular}{lll}
\hline Competency & Reading & Mathematics \\
Educational model & \\
\hline Latin & 470 (FRA: 488) & 474 (FRA: 496) \\
Northern & 503 (Outwith FIN: 492) & 512 (Outwith FIN: 502) \\
Anglo-Saxon & 511 & 507 \\
Germanic & 498 & 518 \\
Est-Asian & 527 & 535 \\
\end{tabular}

Source: OECD, PISA 2006, Data. 
The comparison of performances leads us to distinguish three groups which separate the Latin model (weakly placed), the East-Asian model (strongly placed) and the other three models - Northern, Anglo-Saxon and Germanic - with results close to the OECD average and of which the Germanic system fares better at mathematics and the Anglo-Saxon one at reading.

However, one cannot draw quick conclusions from these first results if we take into account the socio-economic disparities within the population groups represented. The difference in reading results between students of Northern Italy (502) and those of Southern Italy (437) should, on its own, prevent the forming of any deductions with regard to the intrinsic efficiency of an educational system where there are such important geographical contrasts. On another hand, the quality of an educational model depends on its low permeability to local situations. The models where most students have the highest success are those where the influence of institutional factors tends to dominate over that of the situational ones. An indicator for the efficiency of an educational model contrasts, for example, the socio-economic resources of the population with the results reached by the young. For this comparison we refer to the ESCS index of the OECD, which is derived from 5 indices: the parents' socioeconomic status and highest level of education, affluence, families' educational and cultural resources evaluated according to the students' statements regarding household possessions. Through a linear transformation we construct, starting with the measurement of the PISA 2006 ESCS index, a variable $E S C S_{P I S A}$ which allows us to compare the value of this index to the PISA score. ${ }^{11}$

\footnotetext{
${ }^{11}$ In order to be able to compare the values of the variables, the solution is to standardise them so that they may have a $\mu$ average of 0 and a $\sigma$ standard deviation of 1 : $\mathrm{X}_{\mathrm{ESCS}}=\left(\mathrm{ESCS}-\mu_{\mathrm{ESCS}}\right) / \sigma_{\mathrm{ESCS}}$ and $\mathrm{X}_{\mathrm{PISA}}=\left(\mathrm{I}_{\mathrm{PISA}}-\mu_{\mathrm{PISA}}\right) / \sigma_{\mathrm{PISA}}$. In order to make this comparison more meaningful, we have chosen to change the ESCS variable into ESCS with the same average and standard deviation as the average of the mathematics and reading scores of the OECD countries. $\mu_{\mathrm{ESCS}}=0 ; \sigma_{\mathrm{ESCS}}=0,39 ; \mu_{\mathrm{PISA}}=495$ and $\sigma_{\mathrm{PISA}}=29$. Hence $\mathrm{ESCS}_{\mathrm{PISA}}=\mathrm{X}_{\mathrm{ESCS}} * \sigma_{\mathrm{PISA}}+\mu_{\mathrm{PISA}}=$ $495+74.4 *$ ESCS.
} 
Table 3

Comparison of the population's socio-economic level with the average PISA results

(Reading and mathematical knowledge)

\begin{tabular}{lllll}
\hline $\begin{array}{l}\text { Educational } \\
\text { model }\end{array}$ & ESCS & $I_{P I S A}$ & ESCS $S_{P I S A}$ & Direction and magnitude \\
& & & of the difference \\
\hline Latin & $-0,16$ & 472 (FRA: 492) & 484 (FRA: 488) & - \\
Northern & 0,31 & 507 Owth FIN: 498 & 525 Owth FIN: 528 & -- \\
Anglo-Saxon & 0,17 & 509 & 508 & $\approx$ \\
Germanic & 0,20 & 508 & 510 & ++ \\
Est-Asian & $-0,01$ & 531 & 494 & ++ \\
\hline Source: OECD: PISA 2006, Dat & & &
\end{tabular}

Source: OECD: PISA 2006, Data.

This comparison presented in table 3 leads one to further distinguish between three groups of results. Those of the Latin model and of the Northern model are situated below the relative socioeconomic level of the population (with the exception of Finland and, less significantly, France). The results of the Germanic and Anglo-Saxon models are comparable with the socio-economic level of the population (although the average results in United States and Germany are visibly situated below). Finally, the East-Asian model and, within this model, South Korea most notably, presents results which are highly above the socio-economic level of the population (placed in the OECD average). Thus, we arrive at an important result which will be less clear if the economic and cultural differences within population groups are not taken into account. As far as the educational structures are concerned- i.e. assuming they do not hide the action of a third factor which we would have failed to identify- these results give the upper hand to mixed curricula over uniform ones and, within these structural types, to academic orientations over progressive ones.

Countries are nevertheless very different in terms of their immigration policies and the question one must answer is whether one can control the international difference in this respect, in as much as 
the specific problems of children coming from immigrant families are not solely of a socio-economic nature. There are differences between countries not only in terms of the level of immigration (e.g. it is very low, compared with the OECD average, in South Korea, Japan and Finland) and the nature of the immigration (in Canada, Australia and New Zealand the socio-economic and educational levels of the immigrant families are similar, if not superior, to native families). In those countries where the situation of the students coming from immigration multiplies the difficulties, we notice very strong disparities in results between them and native students. However, overall, these big differences act primarily upon educational policies. They do not go as far as contradicting the trends observed in terms of the results within the educational models. The average results of the native students are in fact different only by a few points from those of the students on the whole. Nevertheless, we must note that the relative importance of the immigrant population in the Germanic model (comparable, on average, to its proportion in France) tends to influence more visibly the results, even if the children coming from immigration obtain results which are a little better than in the countries of the Northern or Latin model. ${ }^{12}$ In fact, the mathematics results of the native students in the Germanic model (531 points) bring them close to those of the students in the East Asian model (536 points).

Nevertheless, the PISA survey proves to be of little significance in terms of discriminating between the different educational models, since only their relative efficiency in terms of the students' academic potential is at stake. It is therefore interesting to refer also to the results of the TIMSS survey, which is based on parts of science and mathematics academic programmes analysed trans-nationally (at educational levels where the majority of the students have been through eight years of compulsory education). As a starting point, we will choose the academic potential evaluated by PISA. We would suggest comparing the PISA 2000 mathematics results with those of the TIMSS survey conducted in 1995, which brought together a large number of the countries compared here, starting from a TIMSS $_{\text {PISA }}$ variable which allows us to compare the results from the two surveys.

\footnotetext{
${ }^{12} \mathrm{Cf}$. the detailed report (OECD 2006, 117;180).
} 
Table 4

TIMSS 1995 mathematics results compared with the PISA 2000 mathematics results

\begin{tabular}{|c|c|c|c|c|}
\hline $\begin{array}{l}\text { Educational } \\
\text { model }\end{array}$ & TIMSS & $\operatorname{TIMSS}_{P I S A} *$ & PISA $A_{\text {maths }}$ & $\begin{array}{l}\text { Direction and } \\
\text { magnitude of } \\
\text { the difference }\end{array}$ \\
\hline Latin & 503 (France: 536) & 484 (FRA: 517) & 474 (FRA: 517) & + \\
\hline \multirow[t]{2}{*}{ Northern } & 506 & 491 & 515 & --- \\
\hline & Owth FIN:503 & Owth FIN: 488 & Owth FIN:510 & \\
\hline Anglo-Saxon & 516 & 500 & 516 & -- \\
\hline Germanic & 540 & 519 & 518 & $\approx$ \\
\hline Est-Asian & 606 & 573 & 552 & ++ \\
\hline \multicolumn{5}{|c|}{ Source: IEA, TIMSS 1995 (1999 for Finland and Italy) and OECD; PISA 2000 (2003 for Iceland) } \\
\hline
\end{tabular}

Three levels of performance come out from the results shown in table 4, levels which, this time, clearly distinguish between the models of progressive orientation and those of academic orientation and, within the latter, between the East-Asian model, which has the best results, and the Latin and Germanic models.

The excellent average results of the East Asian students are nevertheless the subject of numerous reservations and this even within the countries concerned themselves. Indeed, in these countries education is supposed to encourage a passive type of learning and to stifle students' creativity. However, the results of the problem-solving test offered by PISA beginning with 2003 (Park, 2006) which requires a creative search for solutions, shows that, on the contrary, the East-Asian type of education represents one of the best methods of training for this type of exercise. Our hypothesis is that the weakness of the East-Asian model is, to a great extent, the result of the pressure placed on students for the entry into high school and university, which orientates school work toward cramming and training for the exam papers and which limits the meaning of achievement to the contest success. 
To this drawback of the East-Asian educational model one also adds a curriculum which is sometimes deemed to be too uniform with regard to the diverse aspirations of the students.

We must note that the worsening of the Japanese students' PISA results between 2000 and 2003 led to the survey being used against the educational principles promoted by OECD through this survey (Takayama, 2008). A drastic revision of the primary school curricula and, furthermore, of the secondary school ones, had taken place in 1999, notably through the development of so-called 'integrated' types of education to make up for a reduction in the academic types. ${ }^{13}$ A new reform emphasising the progressive tendency of the educational reformism was implemented in 2002 and a counter-reform was developed following the PISA 2003 results (Motni 2005).

In short, in order to evaluate the results of the broad educational models at play, we have distinguished three referential levels: economic and cultural conditions, the developed academic potential, and the actual academic success. The comparison shows the clear advantage presented by those systems which propose a form of study course diversification based on the students' achievements and aspirations, and where teaching is academically oriented. Hence, the overall results of the Northern model tend to be diametrically opposed to those of the East-Asian model. The fact that the students' actual successful attainment in the taught subjects are directly linked to the academic orientation of the educational systems is a general and coherent result which does not prejudge the pedagogical adaptation of teaching but concerns the aims of the school programmes.

A double analysis of the French and Finnish cases will show how necessary a close reading of the results of a survey like PISA is.

\section{The weakening of the French students}

As far as the PISA 2006 results are concerned, the basic reading and mathematics results of the French students, especially of the weakest ones among them, have significantly worsened since PISA 2000. The average scores have gone down from 517 to 496 for mathematics and from 505 to 488 for

\footnotetext{
${ }^{13}$ Japanese, social sciences, mathematics, science, music and art were reduced in the first stage of secondary education (collège) in proportions varying from $17 \%$ to $34 \%$. Cf. Cave (2001).
} 
reading. In the area of written comprehension, PISA evaluates to what extent students can make inferences through reading. The most elementary tasks in this respect are found at level 1 . At this level, students can locate a simple element of information, identify the main theme of a text or establish a simple relationship with a shared type of knowledge. Students below this level $(8.5 \%$ in 2006 compared to $4.2 \%$ in 2000) do not manage to complete these tasks. Reading therefore cannot allow them to develop their knowledge during their lives. The percentage of students placed at level 1 or below for written comprehension has increased from $15.2 \%$ in 2000 to $21.8 \%$ in 2006 (the average of the OECD countries is placed at $17.9 \%$ ). The worsening of the weak students' average results is among the most important ones within the OECD countries during this period, whilst the relationship between the students' level of success and their socio-economic and cultural environment has tightened significantly. ${ }^{14}$ The intensity of this relationship was at the OECD average at PISA 2000 and among the strongest for these same countries at PISA 2006.

The French students' weakening is more significant than these data can show because it started before 2000. National analyses show the overall deterioration, since the end of the 1980s, of basic competencies of students finishing primary school. ${ }^{15} \mathrm{We}$ also note a reduction, towards the second part of the 1990s, in the proportion of an age group acceding to general baccalaureate. ${ }^{16}$ General education lost in a few years almost $5 \%$ of an age group. This relatively brutal reduction, at a time when the number of those with a general baccalaureate should have still increased, has been curbed by a

\footnotetext{
${ }^{14}$ Cf. OECD, (2006, 129-131).

${ }^{15}$ Cf. D.E.P.P. (2008). The data in question apply overall to three decades, i.e. 1987, 1997 for reading, 1999 for arithmetic, and 2007. The students' results significantly worsened between the first and third period in reading, arithmetic, as well as spelling (the average number of spelling mistakes at the same dictation went up from 10.7 to 14.7), with a strong increase in the number of no answers to questions which required some writing effort. For reading, the decline was noted in the last period. For arithmetic, the decline pertains mostly to the first period.
}

\footnotetext{
${ }^{16} \mathrm{Cf}$. The statistics published by the ministère de lEducation nationale : Repères et références statistiques sur les enseignements, la formation et la recherche http://media.education.gouv.fr/file/40/4/2404.pdf and also the detailed analyses of Daniel Duverney (2006) with regard to the science section: http://smf.emath.fr/en/Publications/Gazette/2006/110/smf_gazette_110_65-78.pdf
} 
revision of the baccalaureate demands themselves, which resulted in an increase in the success levels. $^{17}$

A quarter of a century ago, the French system of education was considered to be one of the best in the world. Thus, let us take the example of the international survey conducted by IEA (International Project for the Evaluation of Educational Achievement) in 1981-82. It included over 100,000 students from twenty countries (Robin \& Barrier 1985) and looked at testing the level reached by students in class groups where a majority of them were between 13 and 13 and eleven months old, half way through the school year. The results achieved by the French students turned out to be excellent. In a great number of subjects - except geometry, a subject for which the items considered at international level accounted very poorly for the originality of geometry teaching in France, and in the subject area of proportional reasoning - the French average was above the international one. This average would even prove to be higher than the average of the top quartile, in particular, in the subject areas of calculation (estimations and approximations, algebraic calculations, arithmetic calculations, measures), arithmetic, algebra, axiomatics and language change. A comparison with a first survey carried out by IEA in 1964 shows that the average level in mathematics had risen in France for many subject areas, whilst an approximately additional $20 \%$ in an age group were in quatrième ( $8^{\text {th }}$ grade). The school populations of different educational systems were, in this respect, likely to register differences based on the proportion of an age group present in academic streams of study. France was at that time going through a period of transition, as was the case with all of the other countries surveyed, except those of the Anglo-Saxon model (Ireland was an exception with an early division of streams of study). The French collège (junior high school) corresponded to a mixed model, still close to the traditional or Germanic model, to the extent that, at the end of the cinquieme ( $7^{\text {th }}$ grade), vocational studies could start. In fact, in spite of the so-called reform of the "college unique $\square$, which, at the beginning of the 1977 school year, had merged together the various types of institutions -

\footnotetext{
${ }^{17}$ French students went up from $75 \%$ of success at general baccalaureate in 1995 to $88 \%$ in 2007 , which has allowed the issuing of further $5 \%$ of diplomas to one generation and masked the reduction of access to the general baccalaureate.
} 
secondary education collèges (collèges d enseignement secondaire, CES) and general education collèges (collèges denseignement général, CEG) and, theoretically, the streams of study existing inside $\mathrm{CES}^{18}$ - there still was a bifurcation of streams of study at the end of the $7^{\text {th }}$ grade toward vocational education (around 20\% were then leaving general education).

The collège later saw its goals gradually change, particularly beginning with the end of the 1980s. The ideal of offering equal chances to students in order to achieve the best possible intellectual and cultural development progressively gave way to a new ideal, i.e. that of ensuring the acquisition of basic knowledge necessary for leading one's life in society. This ideal was made concrete in the Fillion law of 2005, which assigns compulsory education the objective that everyone acquires a common knowledge and general competencies basis ("socle commun de connaissances et de competences"). Without intending, in theory, to replace the goals of educational programmes, the formulation of various educational objectives in the form of cross-curricular competencies echoes the very educational objectives which lie at the basis of the PISA tests.

A general process of progressive reorientation of the French school was endorsed by the 1989 Loi $d$ Drientation sur lécole ${ }^{19}$ which sets out as its main educational principle the idea that a student must gain knowledge and build his or her personality through his or her own activity. This law lies at the basis of the unification of teacher training through the creation of Higher Education Institutes for Teacher Training (Institutes universitaires de formation des maitres [IUFM] ${ }^{20}$ which became the centres for the dissemination of the new educational orthodoxy (Stal 2008).

\footnotetext{
${ }^{18}$ The students of so-called "transition classes" (special education) had not in fact been integrated in the heterogeneous classes, as required by the reform.

${ }^{19}$ Links to main official texts can be found on: http://www.mapreps.com/pagetextesofficiels.htm and http://www.sauv.net/reforme.htm

${ }^{20}$ These institutes replaced three structures: primary teacher training colleges (écoles normales d'instituteurs), national vocational teacher training colleges (écoles normales nationales d'apprentissage) and regional educational centres (centres pédagogiques régionaux) which trained primary school teachers, vocational school teachers and secondary school teachers respectively.
} 
Following these broad transformations of the School, the educational reform of the college led, in 1996, to a review of the curricula, which marked a rejection of abstraction and formal teaching, and favoured inductive approaches (Demailly 2001; Grange 2005).

Moreover, a curricular uniformity was achieved at the college level during the 1990s. ${ }^{21}$ After 1985, the project to bring $80 \%$ of an age group at the baccalaureate level lead to the closing of short vocational courses, whilst technological-oriented courses were created. These courses were gradually closed after the 1996 renovation. In total, since 1985, and without taking into account the specially adapted classes which represent several percentage points of the student total, all the students from compulsory education were gradually integrated into a shared curriculum, whilst the repeating of academic years was considerably reduced (from 16 to $3 \%$ in $7^{\text {th }}$ grade between 1985 and 2009). ${ }^{22}$

The analyses conducted here contradict the relationship between progressivism, "massification" of school and the democratisation of education. They are also coherent with the fact that the period during which a same age group saw its skills weaken significantly in French and mathematics, that is the fifteen years between 1990 and 2005, coincides with the period when educational policies in France required the overall progressive reorientation of education (Raynaud \& Thibaut 1990; Bulle 2009) and achieved a completely shared core curriculum.

In order to explain this evolution, we must note that a decrease in the intrinsic value of knowledge leads to a demoralisation of education, which encourages students' idleness, whilst a decrease in academic requirements increases the opacity of the standards for schooling achievement, as well as differences between schools. These factors tend to discriminate more against those students who come from modest backgrounds (Cherkaoui 1979; Boudon 2001). ${ }^{23}$

\footnotetext{
${ }^{21}$ For some details cf. http://mde.idf.free.fr/EPLE2/IV.3.\%20renovation\%20colleges.htm

${ }^{22} \mathrm{Cf}$. the statistics published by the ministère de lEducation nationale : Repères et références statistiques sur les enseignements, la formation et la recherche: http://media.education.gouv.fr/file/2001/89/5/rers2001 27895.pdf and http://media.education.gouv.fr/file/2009/87/3/chap4-4 117873.pdf

${ }^{23}$ Cf. also concerning these questions the literature developed around the notion of "school effectiveness" (Cresswell 2004 for a synthetic bibliography)
} 


\section{The Finnish PISA success}

The Finish educational model stands out thanks to its success which clearly separates it from the other educational systems. Certain characteristics of the Finnish system, which meet the orientations required by OECD, are promoted abroad, especially as this small country of five million inhabitants, situated in the far north of Europe, isolated by its language (Finnish) within the European space, tends to escape thorough explorations.

First, let us describe some of the main features of the Finnish basic educational system. Between the end of the 1960s and 1980s, the Finnish educational system witnessed important structural and pedagogical changes. A dual-track school system (beginning after four years of elementary education) had previously separated eight years of compulsory education, including the seven-year civic school, from the humanist and theoretical education of former grammar school. This was replaced in the 1970s with a single system which covered nine years of compulsory education: the comprehensive school - an integrated or polyvalent school. The school later witnessed further changes linked to the increase in the level of teacher training ${ }^{24}$ with extended programs in sciences of education (Kivinien \& Rinne, 1994 ; Kivinien, Rinne \& Simola, 1994 ; Malaty 2004), and to the decentralisation of the educational system at the beginning of the 1990s, the scope of which gained an intermediary place between Norway and Sweden (Ahonen 2001). ${ }^{25}$

\footnotetext{
${ }^{24}$ Since 1979 teachers, no matter the level they practise at, have to complete a university 'Masters' course. The most important changes concern the transition in teacher training from teacher colleges and small-town seminaries to university education departments. Thus, their higher education training was doubled and saw itself crowned with a specialisation in education science dominated by one subject: didactics.

${ }^{25}$ Inspections, detailed national curricula and control over time management disappeared. The only thing that was kept was the number of hours allotted to each subject taught in each school. Schools were now free to choose and the mechanisms for evaluation reinforced. Teachers were in particular being put in charge of developing the curriculum. The increased heterogeneity of students' knowledge requires on their part conducting more social work and can explain the fact that the number of tutored students has grown considerably in over a decade (Webb \& alii, 2004).
} 
Now, in order to explain the success of Finnish students at PISA, one must understand what distinguishes the Finnish model from the Northern model overall, and the young Fins from the young Scandinavians. As we have argued, PISA evaluates a certain academic potential of the student body. This potential hardly depends, if at all, on specific academic competencies effectively developed by the educational systems, or it does very early into the school curriculum. It depends on the low rate of early school failure and, correlative to that, on the success of initial teaching. Institutional and cultural factors explain the important and relatively stable advance of the Finnish school in these two areas.

In Finland, the fight against failure is developed better than almost anywhere else (Kivirauma, Ruoho 2007). It takes different forms. Specialist teachers have the role of assisting teachers by following up, individually or in small groups, on students with particular problems. Very small class groups are established for students with the most serious difficulties. Present evaluations put to almost $30 \%$ the proportion of basic school students (elementary school and first phase of secondary school) who receive special teaching during the academic year, especially in mathematics or Finnish, of which more than $8 \%$ receive special education full-time. ${ }^{26}$ The quick identification of students with difficulties and the handling of the latter in small teaching groups, if not in special classes, is a factor which helps ensure the overall competencies of the student body. It is fair to say, writes sociologist Hannu Simola (2005), that the extent of student homogeneity and the strong system of special education results in the unification and harmonisation of the class groups. The importance of this system of parallel education within the Finnish school tends to bring Finland closer to those systems identified here as mixed, all the more since the curriculum of the first phase of secondary education offers in numerous schools a range of further studies for different subjects (Aho, Pitkänen \& Sahlberg 2006). ${ }^{27}$ We should also note that the teaching of reading poses fewer problems in Finland than in other linguistic and cultural contexts. The very strong grapheme-phoneme correspondence in Finnish

\footnotetext{
${ }^{26}$ Cf. Statistics Finland: http://www.stat.fi/til/erop/index_en.html.

${ }^{27}$ Cf. Also the Finnish National Board of Education's Website: http://www.oph.fi/english
} 
facilitates the first stages of teaching, engaging the use of phonics-based methods and preventing any "war of methods" in this regard, on even regarding other native languages, such as the Swedish.

These conditions together contribute to the quality of teaching in basic education. They would not suffice in fully explaining Finland's PISA success; indeed, they work hand in hand with historicocultural factors. Especially, Finnish teachers enjoy important public confidence. Furthermore, teaching careers are highly valued and the number of candidates is significant, of which only $15 \%$ are selected (this percentage is nevertheless higher in physics and mathematics, which are less in demand). Teachers are described as educationally conservative, in spite of the progressive turn taken by the Finnish educational philosophy in the 1980s. In 1996 a British report (Norris, 1996) showed that, regardless the reform of the curriculum, the latter was in the majority of cases designed for teaching to a whole class and with little individualised forms 'centred on the student'. According to Simola, there is no Finnish 'miracle': the student model, which in PISA is described as very strongly oriented toward the future, seems to lie on values and practices inherited from the past in Finland, leading the educationally progressive comprehensive school reform to more satisfying results than elsewhere.

This success in terms of the academic potential is not translated in a comparable fashion in academic results. As professor George Malaty (2006) notes, PISA does not require the teaching of mathematics as structure: "We know that we would not have any PISA success if we expected our students to understand the mathematical concepts or relationships. The hardest thing for our students is to conduct a demonstration, which is understandable since in our schools we do not learn mathematics as structure'. In the $20^{\text {th }}$ century, until the end of the $1960 \mathrm{~s}$, the mathematics curriculum consisted of algebra and geometry. Then came the reform of modern mathematics, which was followed, beginning with the 1980 s, by the counter-reform movement. The latter led to a focus on the only 'competencies', notably arithmetic, in order to deal with the criticism developed against modern mathematics. The contrasting of conveying competencies on the one hand with conveying knowledge and teaching mathematical structures on the other has led to simply instilling in students practical rules by training them to use them and 'give the correct answers'. The 1998 Basic Education Act has, moreover, defended the idea that 'basic education' should offer each child the knowledge and competencies 
necessary for daily life. As this education does not presuppose learning the fundamentals of mathematics, the students cannot conduct demonstrations nor develop the necessary basis for the subsequent pursuit of higher education studies. This is why the Finnish students' PISA results, at the level of compulsory education, are in contrast with the advice given by mathematics lecturers in higher education. There is among them a consensus with regard to the weakness of the students in this subject area. Lecturers in universities and engineering schools denounce the vicious circle which means having to rework on concepts which should have been mastered in lycée and which were not because in upper secondary school time had to be used to revise concepts which should have been acquired in comprehensive school. They decry the weakness or absence of a shared knowledge basis on which it would be possible to build at the higher level. An 'open letter' on this subject, 'The PISA survey tells only a partial truth of Finnish children's mathematical skills', available on the web, was signed by more than 200 university and polytechnics lecturers. ${ }^{28}$

\section{Conclusion}

The characteristics of the Finnish system which inspire school policies abroad do not lie at the origin of Finland's PISA success. On the contrary, these characteristics are the source of the problems encountered by Finnish students, especially in higher education. Moreover, the weakening of the French students is directly related to educational policies implemented in France, mainly during the past two decades, which follow some of the dominant orientations of the educational philosophy promoted by OECD.

The overall results presented here, which are very synthetic but also strongly significant, show how careless readings of PISA contribute to the international construction of an educational doxa which in

\footnotetext{
${ }^{28} \mathrm{Cf}$. http://solmu.math.helsinki.fi/2005/erik/KivTarEng.html : "Severe shortcomings in Finnish mathematics skills" and http://solmu.math.helsinki.fi/2005/erik/PisaEng.html: "The Pisa survey tells only a partial truth on Finnish children's mathematical skills. A survey conducted in the polytechnics dedicated to applied sciences shows, for example, that $65 \%$ of the Finnish students tested, i.e. 1560 of 2400 , were not able to solve a basic problem which required that one fraction be subtracted from another and the result be divided by a whole number.
} 
reality weakens the national educational systems. The gravest characteristics of this weakening is the domination by a reductionist comparative logic over western school policies, which leaves countries divested of their control over formal education and its profound aims. 


\section{ANNEX}

Table A2

Average scores in reading

\begin{tabular}{|c|c|c|c|c|c|c|c|c|c|}
\hline \multicolumn{2}{|l|}{ Northern } & \multicolumn{2}{|l|}{ Anglo-saxon } & \multicolumn{2}{|l|}{ Latin } & \multicolumn{2}{|l|}{ Germanic } & \multicolumn{2}{|c|}{ Est-Asian } \\
\hline Denmark & 494 & Australia & 513 & Spain & 461 & Germany & 495 & Korea & 556 \\
\hline Finland & 547 & Canada & 527 & France & 488 & Austria & 490 & Japan & 498 \\
\hline Iceland & 484 & United States & 495 & Greece & 460 & Belgium & 501 & & \\
\hline Norway & 484 & Irland & 517 & Italy & 469 & Netherlands & 507 & & \\
\hline Sweden & 507 & New Zealand & 521 & & & Suisse & 499 & & \\
\hline & & United Kingdom & 495 & & & & & & \\
\hline Average & 503 & & 511 & & 470 & & 498 & & 527 \\
\hline
\end{tabular}

Table A3

Average scores in mathematics

\begin{tabular}{|c|c|c|c|c|c|c|c|c|c|}
\hline \multicolumn{2}{|l|}{ Northern } & \multicolumn{2}{|l|}{ Anglo-saxon } & \multicolumn{2}{|l|}{ Latin } & \multicolumn{2}{|l|}{ Germanic } & \multicolumn{2}{|c|}{ Est-Asian } \\
\hline Denmark & 513 & Australia & 520 & Spain & 480 & Germany & 504 & Korea & 547 \\
\hline Finland & 548 & Canada & 527 & France & 496 & Austria & 505 & Japan & 523 \\
\hline Iceland & 506 & United States & 474 & Greece & 459 & Belgium & 520 & & \\
\hline Norway & 490 & Irland & 501 & Italy & 462 & Netherlands & 531 & & \\
\hline Sweden & 502 & New Zealand & 522 & & & Suisse & 530 & & \\
\hline & & United Kingdom & 495 & & & & & & \\
\hline Average & 512 & & 507 & & 474 & & 518 & & 535 \\
\hline
\end{tabular}

Source : PISA 2006 vol.2, Data, p.230

Table A4

Average scores in mathematics

$8^{\mathrm{e}}$ grade

\begin{tabular}{|c|c|c|c|c|c|c|c|c|c|}
\hline \multicolumn{2}{|l|}{ Northern } & \multicolumn{2}{|l|}{ Anglo-saxon } & \multicolumn{2}{|l|}{ Latin } & \multicolumn{2}{|l|}{ Germanic } & \multicolumn{2}{|c|}{ Est-Asian } \\
\hline Denmark & 502 & Australia & 530 & Spain & 487 & Germany & 509 & Korea & 607 \\
\hline Finland & $520: 1999$ & Canada & 527 & France & 538 & Austria & 539 & Japan & 605 \\
\hline Iceland & 487 & United States & 500 & Greece & 484 & Belgium & 565 & & \\
\hline Norway & 503 & Irland & 527 & Italy & 479: 1999 & Netherlands & 541 & & \\
\hline Sweden & 519 & New Zealand & 508 & & & Suisse & 545 & & \\
\hline & & United Kingdom & 506 & & & & & & \\
\hline Average & 503 & & 516 & & 503 & & 40 & & 606 \\
\hline
\end{tabular}

Source: TIMSS1995, p.22. (TIMSS1999 for Finland and Italy)

Table A5

PISA-ESCS Index

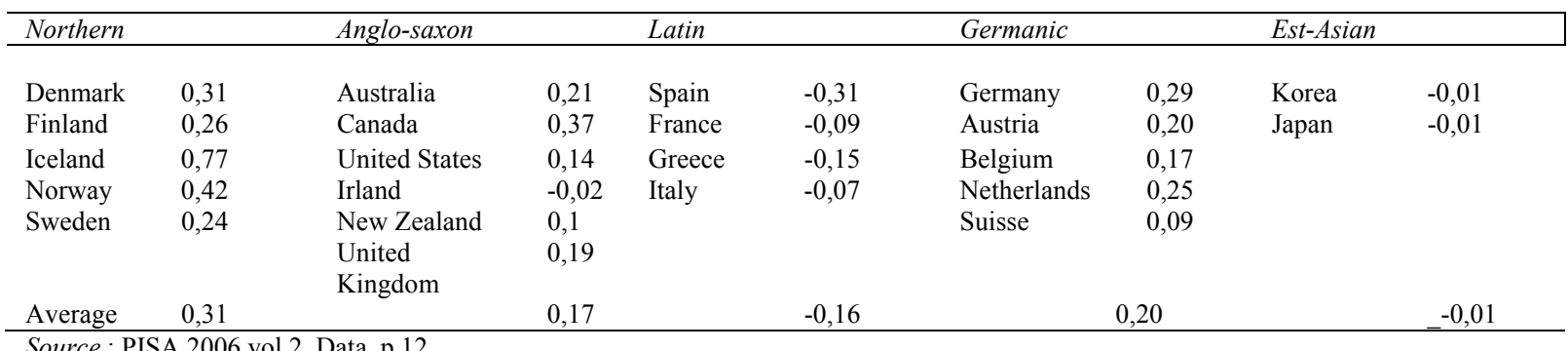

Source : PISA 2006 vol.2, Data, p.12 


\section{References}

Aho, E., Pitkänen K., Sahlberg P. (2006) Policy Development and Reform Principles of Basic and Secondary Education in Finland since 1968 (Washington D.C.: The Worl Bank).

Ahonen, S. (2001), The End of the Common School ? Change in the Ethos and Politics of Education in Finland Towards the End of the 1900s, in Ahonen S. \& J.Rantala (eds), Nordic Lights, Education for Nation and Civic Society in the Nordic Countries, 1850-2000 (Helsinki: The Finnish Literature Society).

Baumert, J., et al. (2001) PISA 2000. Basiskompetenzen von Schülerinnen und Schülern im internationalen Vergleich,Leske+Budrich, Opladen.

Bodin, A. (2007), What does PISA assess? What it doesn't? A French view in Stefan T. Hopmann and al. (Eds.): PISA zufolge PISA. PISA According to PISA (Wien: LIT-Verlag).

Botani „N., Vrignaud, P. (2005) La France et les évaluations internationales (Paris, Haut Conseil d'Evaluation de l'Ecole).

Boudon, R. (2001) Les causes de l'inégalité des chances scolaires in R.Boudon, N.Bulle, M.Cherkaoui (eds) Ecole et Société - Les paradoxes de la démocratie (Paris: PUF).

Bulle, N. (2009) Lécole et son double. Essai sur lévolution pédagogique en France (Paris, Hermann).

Carson, J. (2001) Defining and Selecting Competencies: Historical reflections on the Case of IQ, In D.S.Rychen, L.H.Salganik (Eds), Defining and Selecting Key Competencies (Bern: Hogrefe \& Huber Publishers) pp.33-44.

Cave, P. (2001) Educational Reform in Japan in the 1990s: 'individuality' and other uncertainties, Comparative Education, 37 (2), pp.173-191.

Cherkaoui, M. (1979) Les paradoxes de la réussite scolaire, Sociologie comparée des systèmes denseignement (Paris : PUF).

Cresswell, J. (2004) School Effectiveness (Canberra: The Australian Government Department of Education).

Demailly, J.P. (2001) Rapport au gouvernement sur l lenseignement des sciences (Paris : Institut Fourier).

Duverney, D. (2006), Les spécialités au bac S: une approche historique, Gazette des mathématiciens (110), pp.65-78.

D.E.P.P. (2008), Lire, écrire, compter : les performances des élèves de CM2 à vingt ans d'intervalle 1987-2007, Les notes d'information, $\mathrm{n}^{\circ} 08.38$.

Dohn, N.B. (2007), Knowledge and Skills for PISA - Assessing the Assessment, Journal of Philosophy of Education. 41 (1), pp.1-16.

Goody, J. (2001) Competencies and Education: Contextual Diversity, In D.S.Rychen, L.H.Salganik (Eds) Defining and Selecting Key Competencies (Bern: Hogrefe \& Huber Publishers), pp.174-190. 
Cromley, J.G. (2009) Reading Achievement and Science Proficiency: International Comparisons from the Programme on International Student Assessment, Reading Psychology, 30, pp.89-118.

Grange, M., Happel J. (2005) Rapport sur lenseignement au collège (Paris : Association des Professeurs de Lettres)

Kivinen, O., Rinne R. (1994), The thirst for Learning or Protecting One's Niche? The Shaping of teacher training in Finland during the $19^{\text {th }}$ and $20^{\text {th }}$ centuries, British Journal of Sociology of Education, 15 (4), pp.515-527.

Kivinen, O., Rinne R., Simola H. (1994), Didactic closure: professionalization and pedagogic knowledge in finnish teacher education, Teaching and Teacher Education, 13 (8), pp.877-891.

Kivirauma, J., Ruoho K. (2007), Excellence through special education: Lessons from the Finnish School Reform, Review of Education, 53, pp. 283-302

Levin, B. (1998) An Epidemic of Education Policy: (what) can we learn from each other? Comparative Education, 34 (2), pp.131-141.

Malaty, G. (2004), La formation des enseignants en mathématique en Finlande (Bruxelles : Les cahiers du CeDop).

Malaty, G. (2006) Pisa Results and School Mathematics in Finland: strengths, weaknesses and future, (Joensuu, University of Joensuu).

Motni, Y. (2005) Hopes and challenges for progressive educators in Japan: assessment of the 'progressive turn' in the 2002 educational reform, Comparative Education, 41 (3), pp.309-327.

Norris, N. et al. (1996) An independant evaluation of comprehensive curriculum reform in Finland, (Helsinki, National Board of Education).

Novoa, A. \& Yariv-Mashal, T. (2003) Comparative Research in Education: a mode of governance or a historical journey? Comparative Education, 39 (4), pp.423-438.

Park, H. (2006) Japanese and Korean High Schools and Students in Comparative Perspective, Discussion paper.

Raynaud, P., Thibaud P. (1990) La fin de l école républicaine (Paris : Calmann-Lévy).

Ministère de l'Education nationale (2001, 2006, 2010), Repères et références statistiques sur les enseignements, la formation et la recherche (Paris : MEN)

OECD (2007), PISA 2006: Data, 2 (Paris, OECD).

OECD (2006), Where immigrant students succeed - A comparative review of performance and engagement in PISA 2003 (Paris, OECD).

OECD (2000) Connaissances et compétences : des atouts pour la vie (Paris, OECD).

Prais, S.J. (2003) Cautions on OECD'S Recent Educational Survey (PISA), Oxford Review of Education, 29 (2), pp.139-164.

Robin, D., Barrier, E. (1985) Enquête internationale sur leenseignement des mathématiques (Paris, INRP). 
Salganik, L.S. and al.(1999) Projects on Competencies in the OECD Context, Analysis of Theoretical and Conceptual Foundations, (Neuchâtel, Education Statistics Services Institute).

Shimizu, K. (1992) Education and selection in a Japanese middle school, Comparative Education, 28 (2), pp.109-129.

Simola, H. (2005), The Finnish miracle of PISA : historical and sociological remarks on teaching and teacher education, Comparative Education, 41 (4), pp.455-470.

Sjøberg, S. (2007), PISA and "Real Life Challenges": Mission Impossible?, in Stefan T. Hopmann and al. (Eds.): PISA zufolge PISA. PISA According to PISA (Wien: LIT-Verlag).

Stal, I (2008) Limposture pédagogique (Paris : Perrin).

Stevenson, H.W., Stigler, J.W. (1992) The Learning Gap. Why Our Schools Are Failing and What We Can Learn from Japanese and Chinese Education (New York, Touchstone).

Takayama, K. (2008), The politics of international league tables: PISA in Japan's achievement crisis debate, Comparative Education, 44 (4), pp.387-407.

Uljens, M. (2007) The hidden curriculum of PISA- the promotion of neo-liberal policy by educational assessment 1 in Stefan T. Hopmann and al. (Eds.): PISA zufolge PISA. PISA According to PISA (Wien: LIT-Verlag).

Vrignaud, P., (2008) La mesure de la littératie dans PISA: la méthodologie est la réponse, mais quelle était la question?, Paris, Education et Formations, 78, pp.69-84.

Webb, R. and alii. (2004), A comparative analysis of primary teacher professionalism in England and Finland, Comparative Education, 40 (1), pp.83-107.

Weinert, F.E. (2001) Concept of Competence/ A Conceptual Clarification In D.S.Rychen, L.H.Salganik (Eds), Defining and Selecting Key Competencies (Bern: Hogrefe \& Huber Publishers) pp.45-66. 